\title{
PROGRAM RELOKASI PERMUKIMAN BERBASIS MASYARAKAT \\ UNTUK KORBAN BENCANA ALAM LETUSAN GUNUNG MERAPI TAHUN 2010 \\ (Community Based Resettlement Program for the Victims of Natural Disaster of Merapi Volcano Eruption 2010)
}

\author{
Paulus Bawole \\ Fakultas Arsitektur dan Desain Universitas Kristen Duta Wacana \\ JI. Dr. Wahidin Sudirohusodo No. 5 - 25 Yogyakarta \\ paulus@staff.ukdw.ac.id
}

\begin{abstract}
The most active volcanoes in Indonesia, Mount Merapi erupted with devastating in October and November 2010. Besides some infrastructure facilities are damage, about 2,900 houses were destroyed. 350,000 people were evacuated and accommodated in refugee camps. To accommodate the survivors of Merapi Volcano eruption whose houses were destroyed by the heat clouds it necessary to find a strategy for integrated housing development which is environmental friendly and sustainable.

The strategy which is choosen to implement relocation program for survivors of Merapi eruption is the Community-Driven Resettlement. Community involvement from the beginning of the planning process until the end shows that the power of community involvement in the development process greatly affect the sense of belonging the residential area. By the strategy of Community-Driven Resettlement the inhabitants can keep, maintain, and develop their settlements very well. The development of sustainable resettlements was planned holistically by considering aspects of disaster mitigation, eco-settlement and community livelihood.
\end{abstract}

Keywords: mitigation, settlement, relocation, community-driven.

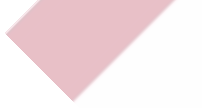

\section{ABSTRAK}

Gunung berapi paling aktif di Indonesia, Gunung Merapi meletus dengan dahsyat pada bulan Oktober dan November 2010. Selain beberapa fasilitas infrastruktur yang rusak, sekitar 2.900 rumah hancur. Sebanyak 350.000 orang dievakuasi dan ditampung di kamp-kamp pengungsi. Untuk mengakomodasi para korban letusan Gunung Merapi yang rumahnya hancur oleh awan panas perlu ditemukan strategi untuk pembangunan perumahan terpadu yang ramah lingkungan dan berkelanjutan.

Strategi yang dipilih untuk melaksanakan program relokasi bagi korban erupsi Merapi adalah Pemukiman Berbasis Masyarakat. Keterlibatan masyarakat dari awal proses perencanaan sampai akhir menunjukkan bahwa kekuatan keterlibatan masyarakat dalam proses pembangunan sangat mempengaruhi rasa memiliki perumahan. Dengan strategi Pemukiman Berbasis Masyarakat penduduk dapat menjaga, memelihara, dan mengembangkan permukiman mereka dengan sangat baik. Pengembangan permukiman berkelanjutan direncanakan secara holistik dengan mempertimbangkan aspek mitigasi bencana, eco-pemukiman dan mata pencaharian masyarakat.

Kata kunci: mitigasi, permukiman, relokasi, berbasis masyarakat. 


\section{PENDAHULUAN}

Suasana mencekam menyelimuti seluruh masyarakat yang tinggal di kawasan lereng Gunung Merapi pada saat BPPTKG mengumumkan status tertinggi Gunung Merapi "awas" pada awal bulan Oktober 2010. Kawasan lereng Gunung Merapi masuk dalam wilayah Kabupaten Sleman di DIY, Kabupaten Klaten, Magelang dan Boyolali di Propinsi Jawa Tengah. Suasana mencekam ini menjadi kenyataan pada saat Gunung Merapi meletus tepat pukul 18.00, tanggal 26 Oktober 2010. Pada saat itu sirene ambulan dan mobil polisi tidak hentihentinya berbunyi di sepanjang Jalan Kaliurang, karena mereka berusaha membawa korban dan mengevakuasi masyarakat yang sulit diajak turun ke tempat yang lebih aman.

Salah satu korban, Mbah Marijan, tokoh dan pemimpin spiritual masyarakat lereng Merapi juga menghembuskan nafas yang terakhir di Dusun Kinahrejo, Desa Hargobinangun, Kecamatan Pakem Kabupaten Sleman. Masih teringat bagaimana tim Gastronome, Arsitektur A17 - ITS pada Tahun 1984 harus tinggal di Kinahrejo dan bertemu dengan mbah Marijan untuk mendapatkan wejangan beliau sebelum mendaki Gunung Merapi. Kearifan beliau yang selalu menekankan penghormatan terhadap budaya lokal dan alam sekitarnya tetap terngiang di telinga sampai saat ini, walaupun jasad beliau sudah menyatu dengan alam yang beliau cinta.
Mulai tanggal 26 Oktober 2010 sampai dengan akhir 5 November 2010, Gunung Merapi meletus tidak hanya sekali, tetapi delapan kali. Semua masyarakat yang tinggal di desa yang berjarak 20 kilometer dari kawah gunung Merapi dievakuasi. Letusan Gunung Merapi pada tahun 2010 ini berbeda dengan letusan biasanya, karena letusan waktu itu menyebabkan runtuhnya kawah Merapi yang menyebabkan aliran lahar dan awan panas (pyroclastic flows) sejauh lebih darii $10 \mathrm{~km}$ (lihat gambar 1). Berdasarkam tulisan bapak Iguchi letusan pada tanggal 26 Oktober menghancurkan bibir kawah yang terbentuk pada letusan tahun 2006 dan letusan pada tanggal 3 - 5 November jauh lebih dasyat dari letusan-letusan sebelumnya (Iguchi, 2011).

Selama akhir bulan Okober 2010 sampai dengan awal November 2010 Gunung Merapi memuntahkan awan panas ke beberapa wilayah pedesaan di lereng Merapi dan aliran lava panasnya mengalir melalui Sungai Gendol dan Opak. Hujan abu melingkupi wilayah propinsi Jawa Tengah dan DI Yogyakarta. Lapangan Udara Adisucipto ditutup beberapa hari karena hujan abu. Masyarakat yang tinggal di desa-desa dalam radius $20 \mathrm{~km}$ dari kawah Gunung Merapi dievakuasi dan abu volkanik yang dilontarkan menyebabkan masalah kesehatan (Bank Dunia, 2012).

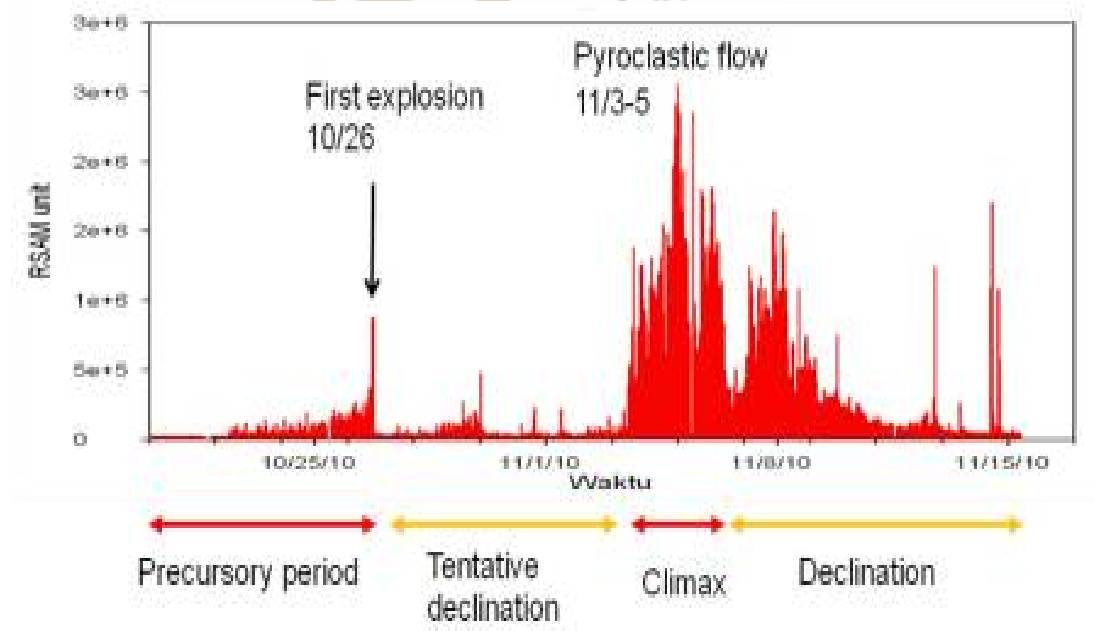

Gambar 1. Perubahan Temporal RSAM (Real-time Seismic Amplitude Measurement) selama periode 20 October - 15 November 2010 (Sumber: IGUCHI, etc. (2011) 


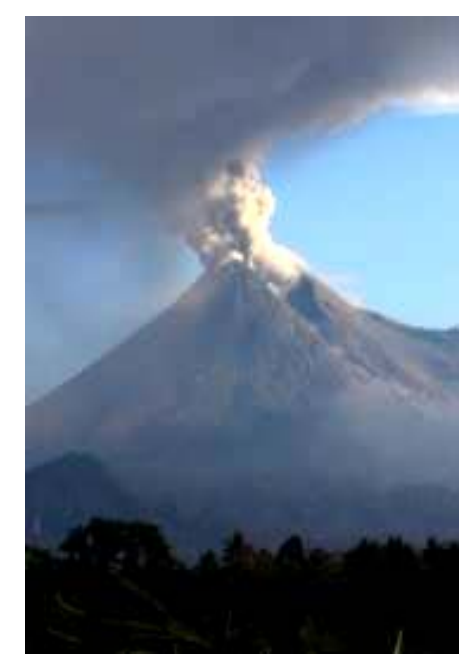

Gambar 2. Letusan Merapi tanggal 13 November 2010 (Sumber: Dokumen Penulis: 2010)

Berdasarkan informasi dari Sekretariat MDF dan IDF awan panas yang membawa abu panas dan gas beracun dengan suhu antara $600^{\circ}-800^{\circ} \mathrm{C}$ membakar apa saja yang dilaluinya, termasuk ternak sapi, kambing, tanaman pertanian dan perkebunan, pohon-pohon buah yang menjadi tumpuhan hidup masyarakat di lereng Merapi. Masyarakat yang berusaha melindungi ternak-ternak piaraan mereka dan tidak mau pergi dari tempat tinggal mereka juga meninggal akibat awan panas yang dihembuskan oleh kawah gunung Merapi (The Secretariat of MDF \& IDF, 2012).

Selain kerusakan infrastruktur yang sangat besar, sekitar 2.900 rumah hancur dan 350.000 orang dievakuasi dan ditampung di kamp-kamp pengungsian. Tanggap darurat yang dilakukan menampung 350.000 pengungsi dibangunlah camp-camp pengungsian di Daerah Istimewa Yogyakarta (Hidayati, dkk., 2013). Hampir semua institusi di DIY seperti Institusi Pendidikan Tinggi, Institusi Keagamaan, LSM, bahkan pihak Swasta berusaha membangun temporary shelters untuk korban Merapi. Sedangkan untuk mengakomodasi 2.900 keluarga yang rumahnya hancur akibat awan panas dan lahar dingin dari Gunung Merapi, diperlukan strategi pembangunan rumah yang terpadu, akrab terhadap lingkungan (environmental friendly), berkelanjutan (sustainable) dan pengembangannya dapat meningkatkan taraf hidup dan tingkat ekonominya. Mitigasi bencana adalah serangkaian upaya untuk mengurangi risiko bencana, baik melalui pembangunan fisik kemampuan menghadapi ancaman bencana (pasal 1 ayat 6 PP no. 21 Tahun 2008 tentang Penyelenggaraan Penanggulangan Bencana).

\section{a. Korban Bencana Letusan Gunung Merapi \\ Seperti sudah dijelaskan di atas} bahwa letusan gunung Merapi bukan hanya menelan korban manusia melainkan menghancurkan seluruh kehidupan dan penghidupan (livelihood) masyarakat yang tinggal di lereng gunung Merapi. Seluruh hasil pertanian, perkebunan dan pohonpohon buah yang menjadi mata pencaharian masyarakat luluh lantak terkabakar awan panas bahkan terkubur oleh lahar yang dimuntahkan gunung Merapi (Bawole, 2014). Pada gambar 2 dapat dilihat bagaimana lahar panas menghancurkan livelihood masyarakat di lereng Merapi. Wilayah Kecamatan Cangkringan merupakan wilayah yang paling parah terkena awan panas, lahar dingin, dan abu vulkanik. Hal ini disebabkan karena kedua sungai besar, Sungai Gondang dan Opak melewati beberapa desa yang masuk dalam wilayah Kecamatan Cangkringan. Dari kelima desa yang ada di Kecamatan Cangkringan rumah warga Desa Galagahharjo dan Kepuharjo yang terbanyak mengalami rusak berat (lihat tabel 1 ).

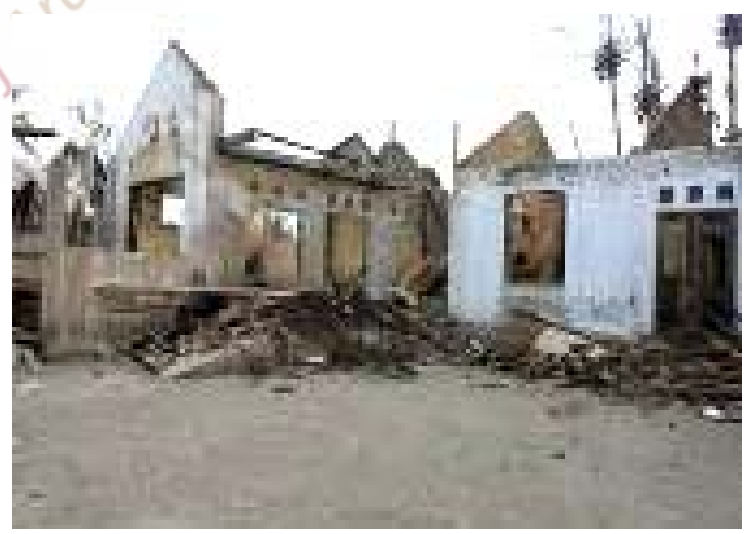

Gambar 3. Situasi Desa Kepuharjo setelah letusan Gunung Merapi pada Bulan Oktober - November 2010 (Sumber : Dokumentasi Penulis, 2010). 
Tabel 1. Data Dusun dan Rumah yang Rusak (tabel diketik ulang)

\begin{tabular}{|lcc|}
\hline \multicolumn{1}{|c|}{ LOKASI } & $\begin{array}{c}\text { Dusun } \\
\text { Rusak }\end{array}$ & $\begin{array}{c}\text { Rumah } \\
\text { Rusak Berat }\end{array}$ \\
\hline Kecamatan Cangkringan & 282 \\
\hline $\begin{array}{l}\text { 1. Desa } \\
\text { Umbulharjo }\end{array}$ & 3 & 829 \\
\hline $\begin{array}{l}\text { 2. Desa } \\
\text { Glagahharjo }\end{array}$ & 8 & 830 \\
\hline $\begin{array}{l}\text { 3. Desa } \\
\text { Kepuharjo }\end{array}$ & 8 & 338 \\
\hline $\begin{array}{l}\text { 4. Desa } \\
\text { Wukirsari }\end{array}$ & 4 & 129 \\
\hline $\begin{array}{l}\text { 5. Desa } \\
\text { Argomulyo }\end{array}$ & 4 & 15 \\
\hline $\begin{array}{l}\text { 6. Desa } \\
\text { Sindumartani }\end{array}$ & 1 & \\
\hline Kecamatan Ngemplak & & $\mathbf{2 8 1 1}$ \\
\hline JUMLAH & $\mathbf{2 8}$ & \\
\hline
\end{tabular}

(Sumber : Data dari Kades per 18-11-2010)

Sebagai respon masyarakat DIY dan kepedulian umat manusia dari negeri tercinta Indonesia dan dari luar negeri banyak tempat pengungsian (refugee camps) dibangun di wilayah DIY dan Propinsi Jawa Tengah. Ratusan bahkan ribuan orang ditampung dalam refugee camps yang dibangun oleh pemerintah daerah, institusi pendidikan, institusi keagamaan, LSM sampai dengan institusi swasta lainnya.

Banyak institusi dari luar kota Yogyakarta yang mendirikan base camp untuk melayani para pengungsi dari lereng Gunung Merapi yang turun ke kota Yogyakarta, Magelang, Klaten dan Boyolali. Semua institusi menyediakan makanan tiga kali sehari untuk para pengungsi, bahkan pakaian, obat-obatan dan tim - tim dokter dari berbagai institusi berkeliling ke tempat penampung pengungsi dan relawan yang menderita sakit. Pada gambar 4, 5, dan 6 dapat dilihat dengan jelas bagaimana keadaan di tempat pengungsian dan usaha relawan dalam bidang medis dan dapur umum yang disiapkan Universitas Kristen Duta Wacana, Yogyakarta untuk melayani para pengungsi. Selain itu mahasiswa secara sukarela juga membangun toilet umum sementara yang akan dimanfaatkan sebanyak 1.500 orang pengsungsi.
Segera setelah tanggap darurat dilakukan dengan menampung para pengungsi di refugee camps pihak pemerintah, swasta, dan LSM yang bekerja sama dengan institusi-institusi pendidikan membangun banyak hunian sementara (temporary settlements) di beberapa lokasi yang aman. Bentuk arsitektural temporary settlement sangat sederhana, kebanyakan menggunakan bentuk atap kampung, dinding anyaman bambu (ada juga yang semi permanen - separuh batako) dan lantai plesteran semen atau dari tanah. Beberapa lokasi temporary settlement dibangun hanya dengan tendatenda darurat saja. Masalah besar di Camp Pengungsian adalah fasilitas KM dan WC, karena jumlah pengungsi sangat banyak, semetara fasilitas WC/KM yang ada hanya beberapa kamar saja. Oleh sebab itu banyak institusi yang memberikan bantuan dengan membangun temporary toilet dengan jumlah yang banyak (lihat gambar 7). Kualitas lingkungan di sekitar temporary settlement sedapat mungkin juga dijaga kualitasnya. Fasilitas-fasilitas technical infrastructure seperti listrik, air bersih dan drainage serta fasiltas social infrastructure seperti tempat bermain anak, ruang terbuka umum, rumah ibadah, pos ronda dan ruang-ruang pertemuan juga disediakan di Temporary Settlement. (Budiman, dkk., 2010).

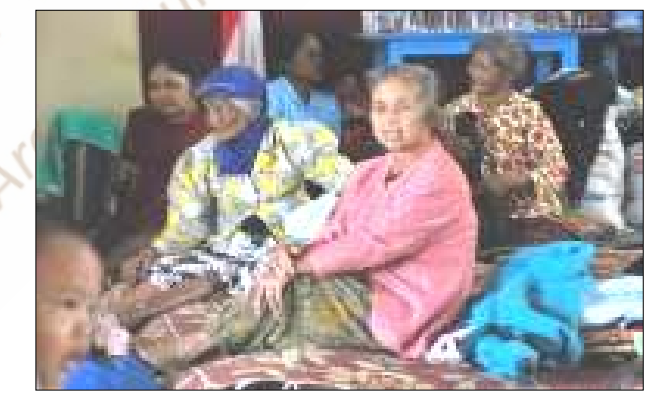

Gambar 4. Situasi di tempat pengungsian korban letusan Gunung Merapi (Sumber: Dokumen Penulis, 2010)

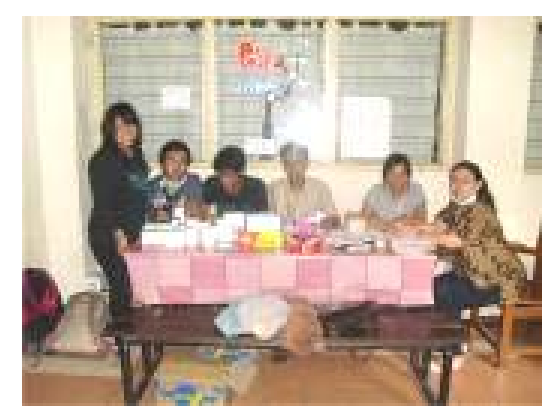


Gambar 5. Klinik Kesehatan Darurat di camp pengungsuan yang disiapkan oleh UK Duta Wacana (Sumber: Dokumen Penulis, 2010)

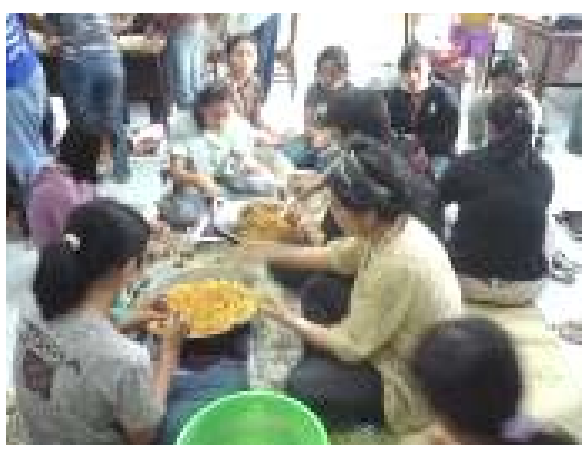

Gambar 6. Dapur Umum di camp pengungsuan yang disiapkan oleh UK Duta Wacana (Sumber: Dokumen Penulis, 2010)

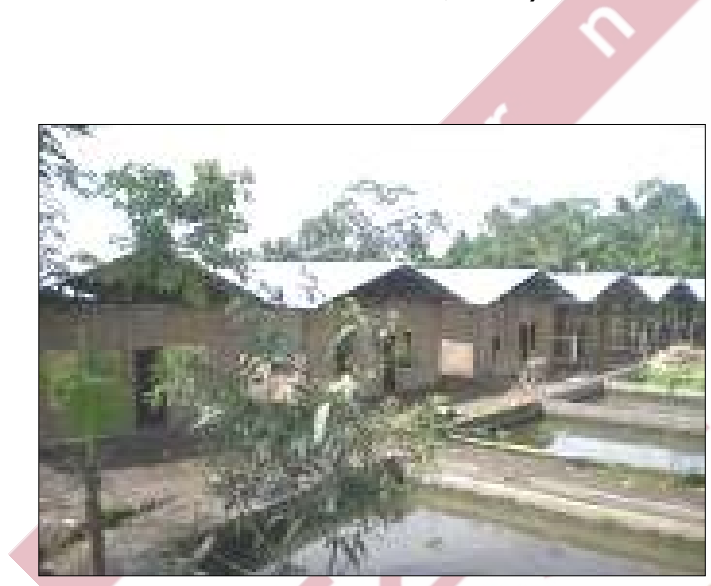

Gambar 7. Pembangunan Hunian Sementara (Temporary Settlement) di Dusun Kuwang, Desa Wukirsari, Kec. Cangkringan - Kab. Sleman (Sumber: Dokumen Penulis, 2010)

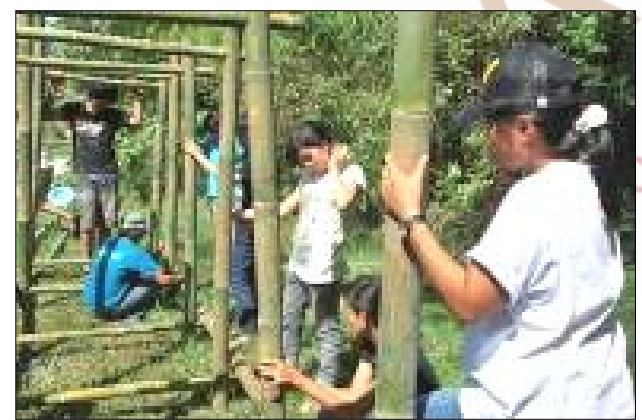

Gambar 8. Mahasiswa Arsitektur UK Duta Wacana Membangun Toilet Umum Darurat di Desa Dukun, Kabupaten Magelang (Sumber: Dokumen Penulis, 2010).

\section{b. Permasalahan dan Tujuan Penelitian}

Dengan mengamati proses awal meletusnya Gunung Merapi sampai proses pembangunan relokasi permukiman masyarakat korban letusan Gunung Merapi dapat ditarik beberapa permasalahan yang nantinya akan dipecahkan dengan melakukan relokasi permukiman pada lahan yang dipertimbangkan cukup aman untuk dijadikan tempat hunian. Permasalahan yang dihadapi dalam melakukan relokasi permukiman korban letusan Gunung Merapi antara lain:

- Kedasyatan letusan gunung Merapi pada tahun 2010 membuat masyarakat yang tinggal di lereng Gunung Merapi menjadi terpuruk pada tingkat yang paling rendah.

- Jumlah keluarga (korban letusan gunung Merapi) yang membutuhkan rumah di tempat yang aman sangat banyak, lebih dari 1000 keluarga.

- Terbatasnya lahan (Tanah Kas Desa) yang akan dipakai sebagai tempat relokasi tidak sebanding dengan banyaknya keluarga yang menjadi korban.

- Ketergantungan penghidupan keluarga (Family Livelihood) pada lahan berbahaya di lereng Merapi, terutama yang berkaitan dengan pemeliharaan sapi perah atau penggemukan sapi.

- Pemahaman masyarakat pada penataan keseimbangan lingkungan masih belum terlalu tinggi.

Untuk mengatasi permasalahan di atas banyak strategi yang diterapkan oleh pemerintah daerah dan pusat dengan bantuan lembaga donor seperti Bank Dunia dan beberapa lembaga donor lainnya, dalam rangka membantu masyarakat lereng Gunung Merapi untuk bangkit dari keterpurukan yang mereka alami akibat letusan Gunung Merapi. Salah satu strategi yang diterapkan adalah Relokasi Permukiman Berbasis Masyarakat (Community Driven Resettlement). 
Berdasarkan latar belakang dan permasalahan yang diungkapkan di atas, maka tujuan penelitian adalah sebagai berikut.

- Mengetahui efisiensi pelaksanaan program resettlement yang terkait dengan bencana letusan gunung berapi.

- Memahami seberapa besar pengaruh kesuksesan program resettlement dengan melibatkan masyarakat pada proses secara keseluruhan.

- Mengetahui seberapa besar manfaat resettlement bagi masyarakat yang dipindahkan ke lokasi yang baru.

- Mengetahui apakah ada proses pemberdayaan masyarakat (community empowerment) dalam program relokasi permukiman berbasis masyarakat di lereng Gunung Merapi.

- Seberapa jauh mitigasi bencana dilaksanakan dalan proses relokasi permukiman akibat letusan Gunung Merapi tahun 2010.

\section{METODE PENELITIAN}

Penelitian ini didasarkan pada pengalaman empiris yang dilakukan mulai dari awal terjadinya bencana sampai pada proses pembangunan relokasi permukiman untuk korban letusan Gunung Merapi tahun 2010. Sedangkan metode penelitian yang dipergunakan untuk melakukan penelitian lebih banyak menggunakan metode kualitatif. Sedangkan metode kuantitatif dipergunakan untuk membaca situasi yang dapat dihitung prosentasenya atau dapat dihitung secara kualitatif. Diharapkan dengan menggunakan kedua metode penelitian ini, informasi dan pembelajaran tentang proses resettlement yang berhubungan dengan kebencanaan khususnya bencana letusan gunung berapi dapat diambil sebagai landasan untuk mengembangkan program resettlement di masa yang akan datang.

\section{KAJIAN TEORI}

Dalam melaksanakan penelitian yang sudah dilakukan, ada beberapa teori yang dipergunakan baik yang terkait dengan metode penelitian maupun teori yang berkaitan dengan permukiman.

\section{Penelitian Tindakan}

Salah satu strategi memahami karakteristik permukiman adalah dengan melakukan action research atau penelitian tindakan yang menggunakan pendekatan total partisipatif. Dengan pendekatan total partisipatif tersebut penelitian tindakan akan berusaha memahami kehidupan masyarakat beserta dengan segala kreativitas mereka dalam mengembangkan rumah dan lingkungan di sekitarnya.

$\begin{array}{clr}\text { Ada banyak definisi penelitian } \\ \text { tindakan } & \text { (action research) yang }\end{array}$ diperkenalkan oleh para peneliti, terutama peneliti yang berkecimpung dalam bidang ilmu sosial. Penelitian tindakan adalah penelitian yang difokuskan untuk meningkatkan kualitas suatu komunitas atau masyarakat beserta dengan kapasitasnya. Secara khusus penelitian ini dirancang dan dilaksanakan oleh praktisi yang berusaha menganalisa data-data dengan teliti untuk meningkatkan kapabilitas mereka.

Penelitian tindakan mempunyai tujuan untuk memberikan kontribusi pada pengembangan kehidupan masyarakat atau komunitas tertentu dalam suatu situasi problematik yang mendesak. Selain itu penelitian tindakan juga memberikan kontribusi pada pengembangan tujuantujuan ilmu sosial dengan kerja sama kolaborasi dalam suatu kerangka etik yang saling dapat diterima (Rapoport, 1977).

Situasi dalam penelitian tindakan (action research) harus dilakukan oleh peneliti dengan obyek penelitian (partisipan) yang sudah ditentukan. Proses penelitian ini walaupun bisa berhenti sampai pada kesimpulan pertama, tetapi pada umumnya proses dilanjutkan dengan kesimpulan awal sebagai input untuk proses penelitian selanjutnya. Setelah hasil penelitian yang didapatkan cukup signifikan dengan standar penelitian, maka kesimpulan yang didapatkan dapat dipublikasikan ke masyarakat (Madya, 2006 disitasi oleh Chandra, 2008).

\section{Permukiman}

Rumah

Yudohusodo adalah bangunan yang berfungsi sebagai tempat tinggal atau hunian dan sarana pembinaan keluarga. (Yudohusodo, 1991). Demikian juga menurut UU No. 4 Tahun 1992 rumah 
merupakan bangunan yang berfungsi sebagai tempat tinggal atau hunian dan sarana pembinaan keluarga. Dari kedua pengertian tersebut dapat disimpulkan bahwa pemahaman terhadap rumah, selain berfungsi sebagai tempat tinggal atau hunian yang digunakan untuk berlindung dari gangguan iklim dan makhluk hidup lainnya, rumah merupakan tempat awal pengembangan kehidupan sosial. Permukiman berkembang baik di daerah pedesaan dengan karakter fisik yang didominasi oleh banyaknya ruang terbuka, maupun di perkotaan yang didominasi banyaknya daerah terbangun. Karena kebutuhan akan rumah terus berkembang, maka banyak rumah yang berkembang pada daerah-daerah yang rawan terhadap bencana.

Pemukiman yang mempunyai resiko bencana tinggi biasanya ditemukan di daerah yang paling sensitif lingkungannya, seperti permukiman yang mengelilingi sistem hidrolik suatu kawasan atau di daerah lereng pegunungan yang mempunyai peranan cukup penting dalam dinamika ekosistem. Bagaimanapun juga, tidak adanya perencanaan penggunaan lahan (land use plan) sebagai pedoman dalam menentukan lokasi dimana manusia dapat bermukim; kelemahan institusional dalam menegakkan undang-undang dan peraturan yang relevan, dan tidak adanya program perumahan untuk masyarakat berpenghasilan rendah cenderung mengakibatkan pemukiman manusia di daerah berisiko tinggi (Correa, 2011).

Pada kasus di lereng Gunung Merapi, banyak permukiman yang hancur berantakan karena terkena awan panas atau lahar dingin. Permukiman yang dahulunya dibangun di lereng Merapi dengan radius sekitar 3 sampai $5 \mathrm{~km}$ dari puncak Merapi merupakan permukiman yang rawan terhadap bencana letusan Gunung Merapi.

Pada letusan Gunung Merapi tahun 2010, rumah-rumah yang ada terbakar oleh awan panas $\pm 600^{\circ} \mathrm{C}$ atau hanyut dibawa derasnya arus lava yang mengalir cepat dari puncak. Karena kondisi di atas yang sangat rentan terhadap bencana letusan Gunung Merapi, maka pihak pemerintahl daerah menentukan kawasan di lereng Merapi menjadi kawasan yang tidak diperkenankan sebagai tempat bermukim. Karena banyak keluarga yang kehilangan rumah dan lokasi rumah mereka sudah tidak boleh lagi untuk tempat tinggal, maka pihak pemerintah daerah wajib melaksanakan program resettlement pada lokasi-lokasi yang tidak jauh dari lereng Merapi, tetapi berada pada daerah yang aman dari letusan Gunung Merapi.

Relokasi permukiman untuk pencegahan yang terletak di daerah berisiko tinggi adalah ukuran korektif di mana seluruh atau sebagian dari masyarakat yang direlokasi karena risiko bencana tinggi. Ukuran seperti itu harus dilihat sebagai upaya terakhir, ketika tidak mungkin untuk mengurangi faktor risiko yang terkait, misalnya, dengan tanah longsor, kemungkinan letusan gunung berapi, atau banjir yang tidak dapat dikontrol.

Relokasi penduduk yang tinggal di daerah berisiko tinggi dapat menghilangkan biaya yang berkaitan dengan respon darurat dan rekonstruksi. Tentu saja, hilangnya kehidupan, infrastruktur dan aset, serta kerusakan lainnya, semua dapat berkurang baik secara moneter dan non-moneter. Seperti sudah dijelaskan sebelumnya bahwa proses relokasi ini juga dilaksanakan paska erupsi Gunung Merapi tahun 2010. Perencanaan relokasi di lereng Merapi diharapkan dapat memberdayakan masyarakat yang menjadi korban letusan Gunung Merapi yang rumah dan ladangnya hancur karena awan panas.

Program permukiman kembali (resettlement) harus dapat meningkatkan kesejahteraan masyarakat bukan menambah masalah kemiskinan masyarakat di permukiman yang baru. Keadaan ini menjadi catatan penting sekaligus tantangan bagi Rekompak dalam melakukan program Permukiman Kembali. Seyogyanya pemikiran untuk meningkatkan taraf hidup masyarakat yang akan dipindahkan sudah dilakukan pada saat proses pembuatan site plan, sehingga beberapa antisipasi terjadinya proses penurunan tingkat perekonomian masyarakat dan kwalitas lingkungan dapat dilakukan dengan baik. Dengan demikian setiap keluarga yang dipindahkan pada permukiman baru di lokasi Huntap sudah 
bisa memprediksikan usaha apa yang akan dilakukan untuk meningkatkan taraf hidup keluarga mereka.

Memukimkan kembali masyarakat pada daerah baru, bukan hanya menyediakan fasilitas rumah tinggal beserta segala fasilitas infrastrukturnya, melainkan memindahkan kehidupan masyarakat baik secara individu, keluarga maupun secara komunitas dalam suatu lingkungan yang baru. Oleh sebab itu aspek sosial-budaya, ekonomi dan kualitas lingkungan juga harus dipindahkan bersama-sama dengan rumah mereka. Dengan kata lain melakukan program permukiman kembali berarti memindahkan kehidupan masyarakat seutuhnya termasuk di dalamnya mata pencaharian (livelihood), sosial-budaya (socio-culture) dan kesadaran terhadap lingkungan (environmental awareness). Selain itu interaksi dengan penduduk asli yang tinggal di sekitar lokasi hunian tetap harus menjadi pertimbangan yang kuat dalam merencanakan site plan.

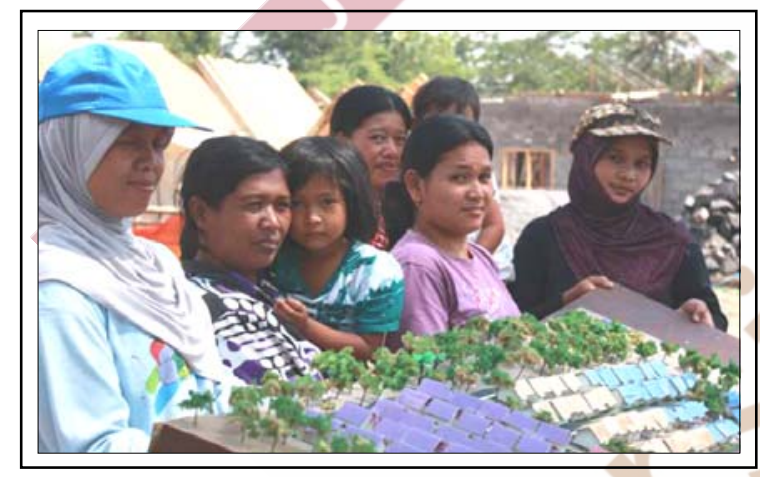

Gambar 9. Situasi ibu-ibu yang sedang mendiskusikan maket model relokasi yang dibuat untuk mempermudah masyarakat membaca kualitas spasial ruang permukiman di tempat relokasi (Sumber: Dokumentasi Penulis, 2010)

Peranan ibu-ibu dalam memberikan kontribusi pemikiran pada diskusi pembuatan site plan menjadi sangat penting dan berarti bagi keberlangsungan kehidupan, karena mereka jauh lebih peka terhadap proses kebutuhan keluarga dibandingkan dengan kaum lelaki.

Pemikiran ibu-ibu ini lebih banyak terkait dengan keselamatan anak-anak dalam bermain di lingkungan permukiman, kemudahan dalam melakukan kegiatan rumah tangga seperti memasak, mencuci dan menjemur pakaian, sampai pada mengantisipasi para suami agar tidak pulang ke rumah terlalu malam dengan cara membatasi jumlah pos ronda yang ada pada permukiman. Ide-ide dari para wanita ini dapat mewarnai pembuatan site plan yang akrab terhadap sosial budaya masyarakat setempat.

Selain melakukan pendampingan pada masyarakat untuk membangun hunian tetap, proses pembelajaran (empowerment) juga dilakukan pada masyarakat berkaitan dengan mengatur pekerjaan pembangunan, mengatur keuangan proyek dan pemberdayaan masyarakat. Masyarakat yang tadinya awam terhadap proses lelang, pengaturan pekerjaan tahapan pembangunan, pengaturan keuangan proyek dan memikirkan dampak lingkungan terhadap pembangunan rumah, secara perlahan melalui Kelompok Pemukim (KP) mereka diajak berdiskusi dan memikirkan sesuai dengan apa yang mereka inginkan. Melalui fasilitator yang terus menerus di lapangan masyarakat diperkenalkan terhadap peraturan perundang-undangan yang berlaku di Indonesia terutama yang berlaku di Daerah Istimewa Yogyakarta.

HASIL PENELITIAN DAN PEMBAHASAN Proses Perencanaan, Perancangan dan Pelaksanaan

Segera setelah para pengungsi sudah menempati Hunian Sementara, pihak pemerinatah daerah dan Dinas Cipta Karya Pusat dengan bantuan dana grand dari Bank Dunia mulai memikirkan permukiman permanen yang nantinya akan ditempati para pengungsi yang sudah tidak diperkenankan kembali tinggal di rumah mereka yang lama. Berdasarkan Peraturan Daerah Kabupaten Sleman No. 12 Tahun 2012 tentang RTRW Kabupaten Sleman ada 9 Dusun yang masuk dalam 3 Desa di Kecamatan Cangkringan yang dilarang untuk permukiman. Masyarakat yang tinggal di 9 dusun tersebut direlokasi pada beberapa wilayah yang dianggap aman dengan rekomendasi dari BPPTK. Ada 3 dusun yang masyarakatnya tidak berkenan direlokasi. Ketiga dusun tersebut masuk dalam wilayah Desa Glagaharjo.

Proses perencanaan sampai dengan pelaksanaan dilakukan dengan melibatkan 
masyarakat secara total. Pada tahap awal masyarakat mulai diperkenalkan dengan konsultan pendamping Rekompak yang akan mendampingi membuat perencanaan sampai dengan implementasinya. Selain itu secara intensif melalui pelatihan-pelatihan dan lokakarya masyarakat dipersiapkan untuk membuat perencanaan relokasi permukiman yang akan menjadi tempat tinggal mereka sendiri. Pada proses ini semua relawan dari masyarakat dan pemangku kepentingan seperti pemerintah daerah, swasta, akademisi, organisasi keagamaan dan LSM dilibatkan dalam proses. Bank Dunia dengan staf-stafnya sebagai lembaga yang memberikan dana bantuan juga terlibat dalam proses melakukan pendampingan baik berupa pelatihan, workshop, diskusi formal dan informal dengan masyarakat maupun diskusi dengan pemerintah daerah untuk memperlancar proses perencanaan sampai implementasi program.
Tahap berikutnya adalah tahap pembuatan site plan sampai tahap mempersiapkan lahan untuk pembangunan permukiman beserta infrastrukturnya. Pada proses ini terjadi transfer of knowledge dari fasilitator dan tenaga ahli pada masyarakat terkait dengan bagaimana melakukan review terhadap perencanaan yang sudah ada, pemetaan swadaya yang akan mencari potensi dan permasalahan, meninjau lahan yang akan dimanfaatkan untuk relokasi, membuat site plan untuk resettlement sampai dengan melakukan pematangan tanah (land clearing) di lokasi site. Dari semua proses yang dijelaskan di atas porses penentuan site plan dan perencanaan infrastruktur merupakan proses yang paling intensif, karena hampir semua masyarakat yang akan melakukan relokasi terlibat dalam proses penentuan site plan termasuk fasilitas infrastruktur yang ada di dalamnya. Proses ini dilakukan berulang kali sampai ada kesepakatan

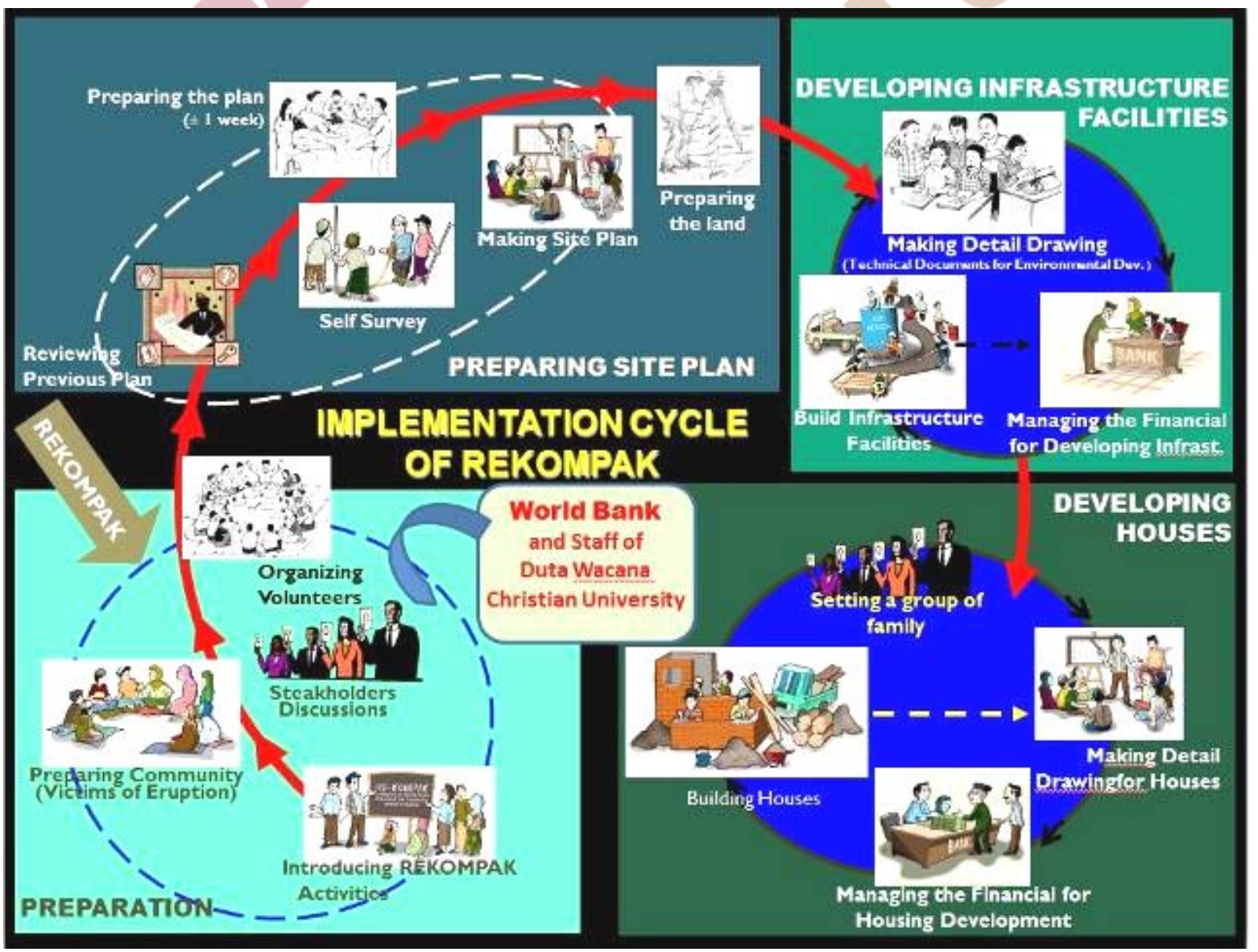

Gambar 10. Proses Perencanaan Relokasi Permukiman Korban Merapi yang Melibatkan Masyarakat di Kabupaten Sleman-DI Yogyakarta Secara Holistik (Sumber: Tim Rekompak tanggal 9 Maret 2012 pada Rapat Koodinasi Teknis di Yogyakarta). 
bersama dengan melibatkan semua pemangku kepentingan termasuk staf dari Bank Dunia yang memberikan bantuan dana untuk pelaksanaan relokasi.

Setelah proses pembuatan DED (Detail Engineering Design) site plan dan pematangan lahan sudah dilakukan proses selanjutnya adalah melaksanakan pembangunan inftrastruktur jalan dan drainage yang kemudian dilanjutkan dengan pembangunan rumah tinggal. Bersamaan dengan itu proses-proses pembelajaran melakukan manajemen konstruksi juga diberikan pada masyarakat atau Kelompok Pemukim. Dengan demikian masyarakat dapat mengatur proses pembangunan baik dari segi konstruksi maupun dari segi manajemen keuangan. Tentu saja proses pengelolaan keuangan ini tidak bisa dilepas langsung melainkan harus dilakukan pendampingan oleh para fasilitator dan tenaga ahli yang dipersiapkan oleh tim Rekompak yang sudah dikontrak oleh Cipta Karya untuk mendampingi masyarakat dan pemerintah daerah dalam melaksanakan program relokasi korban Bencana Letusan Gunung Merapi.

Untuk menjaga kelancaran proses perencanaan sampai pelaksanaan Relokasi ini Monitoring dan Evaluasi selalu dilakukan baik oleh Bapenas, PU - Cipta Karya maupun dari Bank Dunia (Bank Dunia, 2012). Hampir setiap bulan ada kegiatan Rakornis atau Rapat Koordinasi Teknis) yang isinya adalah memonitor dan mengevaluasi perkembangan fisik di lapangan dan audit pengelolaan keuangan.

Pembangunan rumah tipe 36 dengan bantuan dana stimulan sebesar Rp.30.000.000,- yang didanai dengan dana BDR dan pembangunan infrastruktur yang didanai dengan dana BDL dilakukan secara terintegrasi oleh masyarakat dengan didampingi oleh Fasilitator Rekompak. Proses pembangunan rumah dan infrastrukturnya saat ini mendekati 100 $\%$ hampir seluruhnya sudah dihuni oleh para penerima.

Interaksi sosial diantara penghuni sudah mulai terlihat. Keadaan yang luar biasa terlihat adalah pengembangan rumah tinggal inti yang dilakukan oleh masyarakat. Saat ini di beberapa lokasi Huntap (Hunian Tetap) rumah-rumah tinggal yang ada sudah mulai dikembangkan sesuai dengan selera keluarga masing-masing.

Rumah-rumah tinggal yang ada dibangun dengan menambah teras yang diselesaikan dengan cat dan bahan bangunan lain yang bervariasi. Keadaan ini membuat rumah - rumah di lokasi Huntap menjadi lebih berkarakter "Rumah Sebagai Proses" dibandingkan rumah yang dibangun oleh developer yang berkarakter "Rumah sebagai Produk". Keadaan ini terjadi karena keterlibatan masyarakat dalam proses pembangunan rumah dan lingkungannya dilakukan dengan sangat intensif.

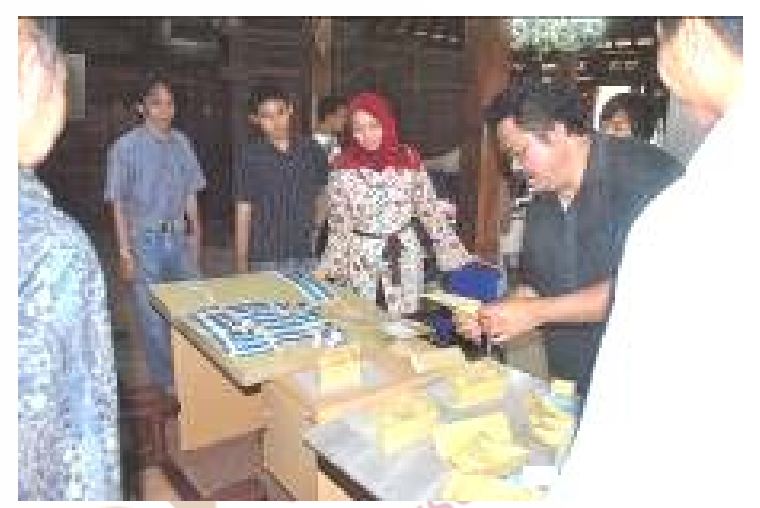

Gambar 11. Proses Transfer of Knowledge dalam Pembuatan Site Plan (Sumber: Dokumentasi Pribadi, 2010).

Demikian juga dengan pemanfaatan infrastruktur transportasi beserta ruang terbuka hijau di lokasi Huntap, mereka berusaha menanam tanaman pada lahanlahan kosong di luar plot rumah tinggal untuk membuat permukiman terlihat lebih asri. Sementara pembangunan instalasi listrik oleh PLN juga berusaha diintegrasikan dalam perencanaan permukiman dan didiskusikan dengan masyarakat yang akan tinggal di Huntap.

Saluran drainage menjadi penting dalam perencanaan permukiman, karena aliran air hujan harus diatur dengan baik agar tidak menggenai wilayah Huntap maupun permukiman asli tempat Huntap didirikan. Pembangunan Septic-tank Communal dan pengelolahan limbah yang menggunakan Lahan Basah Buatan (Artificial Wetland) dapat meningkatkan kualitas lingkungan permukiman yang dikembangkan dengan konsep eco- 
settlement yang berkelanjutan (sustainable eco-settlement). Pada beberapa lokasi dibuat sumur-sumur resapan untuk mengalirkan air hujan agar tidak semuanya mengalir pada permukaan tanah. Dengan penataan lingkungan permukiman yang akrab terhadap lingkungan dan berbasis pada komunitas, pembangunan Huntap bagi masyarakat yang menjadi korban letusan Gunung Merapi dapat dilaksanakan dengan baik.

Bersamaan dengan itu proses-proses pembelajaran melakukan manajemen konstruksi juga diberikan pada masyarakat atau Kelompok Pemukim. Dengan demikian masyarakat dapat mengatur proses pembangunan baik dari segi konstruksi maupun dari segi manajemen keuangan. Tentu saja proses pengelolaan keuangan ini tidak bisa dilepas langsung melainkan harus dilakukan pendampingan oleh para fasilitator dan tenaga ahli yang dipersiapkan oleh tim Rekompak yang sudah dikontrak oleh Cipta Karya untuk mendampingi masyarakat dan pemerintah daerah dalam melaksanakan program relokasi korban Bencana Letusan Gunung Merapi.

Untuk menjaga kelancaran proses perencanaan sampai pelaksanaan relokasi, maka monitoring dan evaluasi selalu dilakukan baik oleh Bapenas, PU - Cipta Karya maupun dari Bank Dunia. Hampir setiap bulan ada kegiatan Rakornis (Rapat Koordinasi Teknis) yang isinya adalah memonitor dan mengevaluasi perkembangan fisik di lapangan dan audit pengelolaan keuangan.

\section{Pendampingan Masyarakat Dalam Membangun Permukiman Berwawasan Ekologi yang Berkelanjutan}

Dari proses perencanaan dan implementasi yang sudah dijelaskan di atas, pendampingan pada masyarakat mutlak dilakukan secara intensif oleh fasilitator dan tenaga ahli dari Rekompak dengan supervisi dari PU-Cipta Karya dan Bank Dunia. Karena proses relokasi yang di lakukan untuk korban letusan Gunung Merapi tahun 2010 dilakukan berbasis masyarakat (community driven program), maka penguatan pada tingkat masyarakat harus dilakukan secara detail dan terperinci. Proses pembelajaran tidak hanya diberikan melalui proses belajarmengajar secara intensif dengan ceramah, melainkan dilakukan juga dengan cara praktek di lapangan atau dilakukan secara simulasi.

Dalam memberikan penguatan pada masyarakat tentang proses relokasi permukiman diperkenalkan juga tentang permukiman berwawasan ekologi yang berkelanjutan (sustainable eco-settlement). Aspek-aspek yang berkaitan dengan Koefisien Dasar Bangunan (Bulding Coverage), Koefisien Luas Lantai Bangunan (Floor area Ratio), pengelolaan Public Space, Drainage, IPAL Komunal, pemanfaatan kotoran ternak untuk biogas dan mitigasi bencana juga diperkenalkan dan berusaha diendapkan dalam pemikiran masyarakat. Dengan pemahaman dan

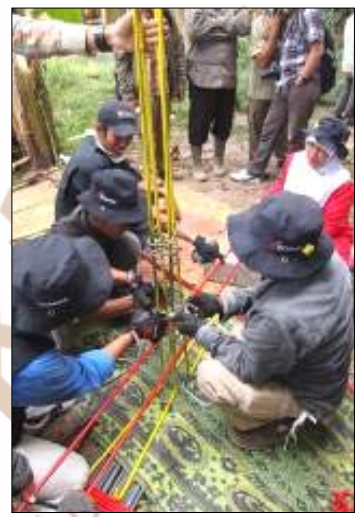

Gambar 12. Proses Pendampingan dan Transfer of Knowledge pada Masyarakat (Sumber: Dokumentasi Pribadi, 2010)

pengendapan pada pemikiran masyarakat tersebut diharapkan kualitas lingkungan pada kawasan relokasi permukiman dapat dijaga terus oleh masyarakat secara berkelanjutan.

Proses pembelajaran ini penting dilakukan untuk menyamakan pengetahuan dan pemahaman terhadap proses pembangunan permukiman baik secara persiapan dan pelaksanaan konstruksi maupun secara manajemen keuangan. Tingkat pendidikan masyarakat bisa dikatakan tidak sama, sehingga proses pembelajaran ini sangat diperlukan oleh masyarakat. Dengan proses pemberdayaan ini diharapkan seluruh masyarakat yang melakukan relokasi mampu membuat perencanaan, pelaksanaan dan mengontrol keuangan 
secara mandiri. Dengan demikian untuk proses pengembangan kawasan relokasi pada massa yang akan datang, masyarakat mampu melakukan evaluasi perencanaan yang sudah mereka buat dan mengembangkannya sesuai dengan karakter dan kapabilitas masyarakat sendiri (Bawole, 2013).

Melalui proses perencanaan relokasi permukiman yang melibatkan masyarakat secara holistik, pembangunan permukiman berkelanjutan yang berwawasan lingkungan dapat diselesaikan dengan baik. Pada program relokasi ini masingmasing keluarga mendapatkan dana Rp. 30.000.000,- untuk membangun core house dengan luas $36 \mathrm{~m}^{2}$ dan sebidang tanah bersertfikat hak milik seluas $100 \mathrm{~m}^{2}$. Untuk fasilitas infrastruktur masing-masing keluarga mendapat dana sebesar Rp. 50.000 .000 ,- yang langsung dikelola untuk pembangunan fasilitas technical dan social infrastructure. Pendampingan masyarakat terus dilanjutkan sampai masyarakat dapat mengelola livelihood mereka yang berkelanjutan.

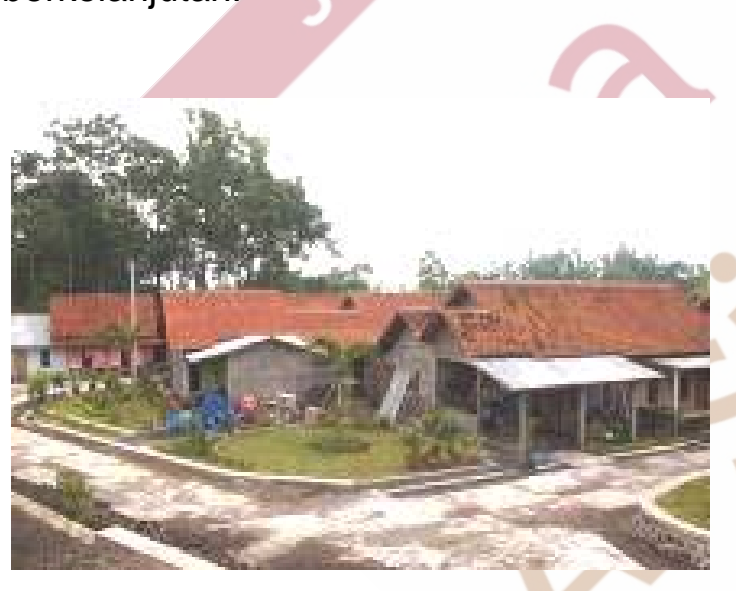

Gambar 13. Pemukiman Berwasan Ekologi yang Berkelanjutan Dengan Semua Fasilitas Infrstrukturnya (Sumber: Dokumentasi Rekompak dan Pribadi, 2010).

Kekuatan keterlibatan masyarakat dalam melaksanakan proses relokasi permukiman untuk korban letusan Gunung Merapi dapat teridentifikasi dari prinsipprinsip Community Driven Program yang diterapkan bersama dengan strategi pengembangan sustainable eco-settlement dan mitigasi bencana.

Dengan pelaksanaan pembangunan Hunian Tetap untuk korban letusan Gunung Merapi yang sudah dilakukan di
Kabupaten Sleman, DI Yogyakarta dan di Kabupaten Magelang, Propinsi Jawa Tengah diharapkan dapat memperoleh pembelajaran terhadap Mitigasi Bencana pada pengembangan permukiman berwawasan ekologi yang berkelanjutan dan berbasis masyarakat. Pembangunan permukiman berbasis masyarakat, mitigasi bencana dan ecology sangat membantu masyarakat yang sangat menderita akibat terkena dampak bencana letusan Gunung Merapi yang maha dahsyat.

\section{Perkembangan Hunian Tetap}

Perkembangan Hunian Tetap saat ini terlihat cukup baik dan hubungan sosial masyarakat di dalamnya terlihat harmonis. Keadaan ini dapat dilihat dari hasil penelitian lapangan Evaluasi Paska Huni (Post Occupation Evaluation) yang dilakukan secara random pada seratus responden yang tinggal di Hunian Tetap Pagerjurang.

Kwalitas permukiman di Huntap Pagerjurang saat ini terlihat cukup baik, karena masyarakat dapat melakukan perawatan fasilitas yang ada di permukiman, terutama penataan ruang luar baik secara privat maupun ruang terbuka umum (gambar 14). Walaupun secara core house Arsitektur Rumah Tinggal dengan atap kampong mempunyai bentuk yang seragam, tapi finishing yang dilakukan masing-masing keluarga berbeda-beda sesuai dengan karakter masing-masing keluarga.

Secara ekonomi kehidupan keluarga terlihat ada peningkatan walaupun peningkatannya tidak terlalu drastis. Pada diagram pie gambar 15 dan 16 terlihat bahwa prosentase yang paling terlihat ada peningkatan adalah prosentase keluarga yang mempunyai penghasilan antara Rp. 3 juta - Rp. 4 juta. Informasi pada diagram sebelum erupsi tercatat $3,85 \%$ sedangkan data pada paska erupsi tercatat 5,77\%. Dengan demikian terjadi peningkatan pendapatan sebesar $1.92 \%$. Berdasarkan hasil observasi di lapangan hubungan interaksi antara keluarga di dalam Huntap terlihat cukup baik. Demikian juga dengan penduduk asli yang tinggal di Pagerjurang, mereka sangat terbuka untuk melakukan aktivitas bersama dengan masyarakat yang tinggal di huntap. 


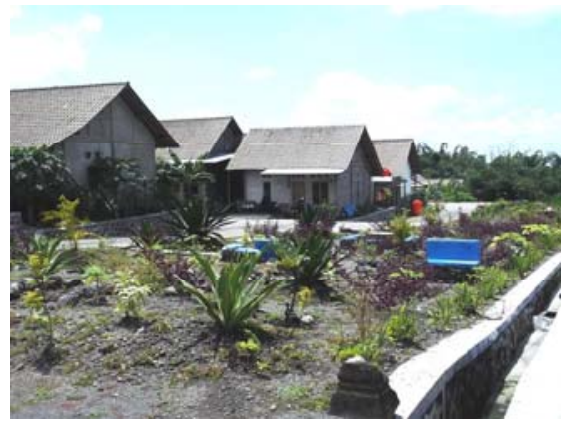

Gambar 14. Keadaan Huntap Pagerjurang saat ini dengan ruang terbuka dengan drainage dan pengolahan ruang terbuka di depan rumah (Sumber: Dokumen Penulis, 2010)

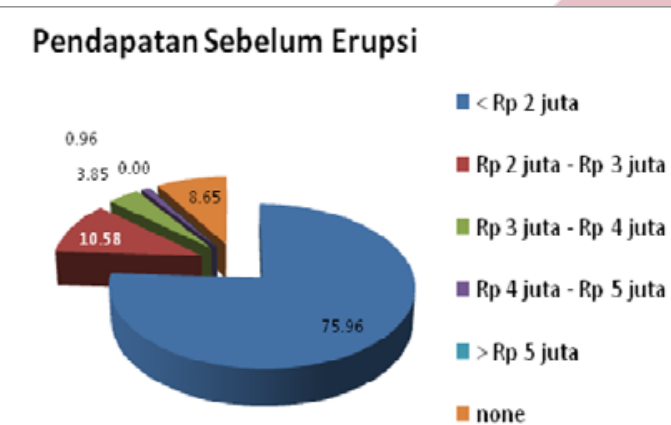

Question number 80 :

Penghasilan keluarga bapak/ibu, sebelum terjadi letusan Merapi tahun 2010?

Gambar 15. Pendapatan Sebelum Erupsi (Sumber: Dokumen Penulis, 2010)

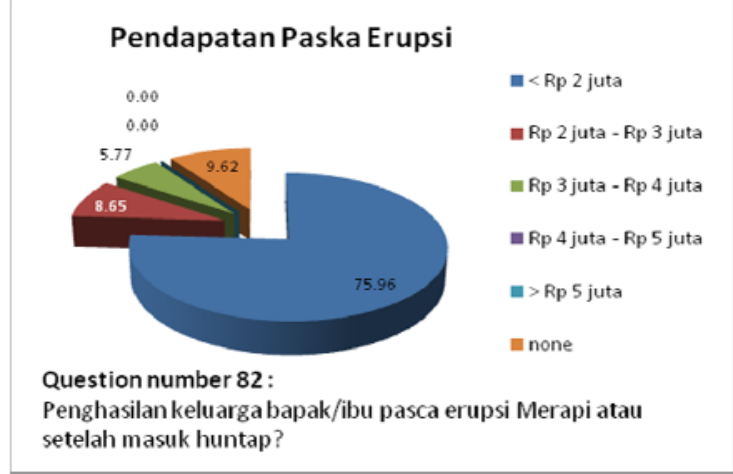

Gambar 16. Pendapatan Paska Erupsi (Sumber: Dokumen Penulis, 2015)

Hal yang terlihat masih menjadi masalah adalah penduduk yang penghidupannya (livelihood) bergantung pada peternakan sapi perah/ Program pemerintah member bantuan satu ekor sapi untuk setiap keluarga dan fasilitas kandang komunal dengan kapasitas sesuai dengan jumlah keluarga yang banyaknya lebih dari 300 keluarga. Apabila sapinya beranak, mereka akan tidak mempunyai kandang untuk anak sapi, sehingga anak sapi tersebut tepaksa dijual. Jadi untuk meningkatkan pendapatan dengan memerlihara sapi masyarakat agak menghadapi kesulitan. Pada akhir-akhir ini sempat terekam beberapa keluarga yang mencoba memelihara sapinya di lokasi rumah lama di kawasan rawan bencana di lereng Merapi.

\section{KESIMPULAN}

Sebagai hasil akhir dari diskusi yang sudah dilakukan pada pembahasan di atas, beberapa kesimpulan dapat ditarik sebagai pedoman dalam melakukan penelitian, perencanaan dan pelaksanaan program relokasi permukiman berbasis masyarakat. Kesimpulan-kesimpulan yang dapat ditarik antara lain :

- Pembangunan permukiman pada daerah relokasi Hunian Tetap menjadi baik apabila keterlibatan masyarakat dilaksanakan sejak dari proses awal.

- Masyarakat jauh lebih tahu tentang kebutuhan dan kapabilitas mereka untuk mengembangkan permukiman dan lingkungan sekitarnya.

- Pemberdayaan masyarakat terkait dengan eco-settlement dan livelihood dapat meningkatkan kesadaran mereka terhadap lingkungan yang berkelanjutan sekaligus dapat meningkatkan standard hidup mereka.

- Mitigasi bencana di wilayah Huntap dapat memberikan rasa tentram pada masyarakat yang tinggal di Hunian Tetap.

- Peningkatan kwalitas rumah secara individu selalu mengikuti pengembangan ruang terbuka umum yang dibangun lebih awal.

- Rencana pengembangan permukiman berkelanjutan direview oleh masyarakat setiap tahun untuk mengaktualisasi program-program pengembangan yang diakses baik dari peremintah daerah maupun dari institusi swasta.

- Relokasi bisa dikatakan cukup penting, tetapi harus selalu disepakati oleh anggota masyarakat secara mayoritas. Tanpa persetujuan masyarakat 
perbedaan antara penggusuran paksa dan relokasi sangat kabur.

- Kekuatan keterlibatan masyarakat dalam proses perencanaan dan pembangunan Permukiman mampu menjaga kestabilan dan keberlanjutan permukiman berwawasan ekologi lingkungan.

\section{DAFTAR PUSTAKA}

Bank Dunia. 2012. "REKOMPAKMembangun Kembali Masyarkat Indonmesia Pasca bencana". Sekretariat Multi Donor Fund dan Nias dan Java Reconstruction Fund.

Bawole, Paulus. 2014. "Community Engagement in Developing Rural Settlement: A Case Study of Village Development around Merapi Volcano in Yogyakarta" in Proceeding of International Conference: Arte-Polis 5 International Conferenc-Reflections on Creativity: Public Engagement and the Making of Place carried out at School of Architecture, Planning and Policy Department - Institute Teknologi Bandung, Bandung.

Bawole, Paulus. 2013. "Pembangunan Permukiman Pasca Erupsi Merapi 2010" in Buletin Lingkungan Hidup "Kalpataru." Badan Lingkungan Hidup DI Yogyakarta. Edisi Desember 2013, p.26-28.

Budiman dan Subandonosaptono. 2010. Membangun Kembali Permukiman dan Lingkungan Pascagempa dan Tsunami Berbasis Masyarakat. Jakarta: Dirjen Cipta Karya, Kementrian Pekerjaan Umum.

Chandra. 2008. Action Research Penelitian

Tindakan.(http://chandrax.wordpress. com/2008/07/05/ action-researchpenelitian-tindakan/)

Community Planning Workshop. 2005. Jackson County - Natural Hazards Mitigation Action Plan. Jackson County Emergency Management, Oregon - USA

Hidayati, Sri; Surono; Subandriyo. 2013. "A year after the 2010 Merapi eruption: volcano hazard and Indonesian government mitigation measures" download on $13^{\text {th }}$ September 2013 from|:

http://miavita.brgm.fr/pressroom

/Pages/ayearafterthe2010Merapierupt ion.aspx

IFRC 2010. "Indonesia: Mt. Merapi Volcanic Eruption" in Information Bulletin No. 1 GLIDE no. VO-2-1000214-IDN, 27 October 2010.

IGUCHI, Masatu, etc. 2011. Learn from 2010 Eruption at Merapi and Sinabung Volcanoes in Indonesia. (http://www.dpri.kyotou.ac.jp/nenpo/no54/ronbunB/ a54b0p22.pdf)

Java Reconstruction Fund - JRF. 2012. Dari Inovasi hingga Praktik Teladan. Laporanm Akhir Java Reconstruction Fund. Unpublished.

JHA, Abhas K. and Stanton-Geddes, Zuzana. 2013. Kuat, Aman, dan Tahan. International Bank for Reconstruction and Development/The World Bank, Washington DC.

NMC and DMC Report in 2012, Unpublished

Madya, S. 2006. Teori dan Praktik Penelitian Tindakan (Action Research), Alfabeta: Bandung.

Rans, Susan and Altman, Hilary. 2002. Asset-Based Strategies for Faith Communities ACTA Publications, Chicago.

Rapoport, Amos. 1977. Human Aspect of Urban Form. Pergamon Press, Oxford.

The Secretariat of MDF and IDF. 2012. REKOMPAK - Rebuilding Indonesia's Communities After Disaster. The World Bank, Jakarta.

Slezin, Yu.B. 2003. "The Mechanism of Volcanic Eruptions (a Steady State Approach)" in Journal of Volcanology and Geothermal Research 122. P. 7 50

Yudohusodo, Siswono, Ir., 1991. Rumah Untuk Seluruh Rakyat. INKOPPOL, Unit Percetakan Bharakerta, Jakarta. 